\title{
SYNTHESIS, PHYSICO-CHEMICAL AND ANTIMICROBIAL EVALUATION OF CO(II) AND NI(II) COMPLEXES WITH SCHIFF BASE DERIVED FROM SULPHANILAMINE AND SALICYLALDEHYDE
}

\author{
Siraj, I. T. and Yusuf, B.A. \\ Department of Pure and Industrial Chemistry, Bayero University, Kano. Nigeria \\ tCorresponding auth: itsirajo.chm@buk.edu.ng
}

\section{ABSTRACT}

Schiff base derived from sulphanilamine and salicylaldehyde was synthesized, its reaction with nickel(II) and cobalt(II) chloride in 2:1 mole ratio yielded Ni(II) and Co(II) complexes respectively. The synthesized compounds were characterized based on melting point/decomposition temperature, solubility, molar conductance, magnetic susceptibility and infrared spectral analyses. The complexes have low molar conductance value (31.4-32.6 $\left.{ }^{1} \mathrm{~cm}^{2} \mathrm{~mol}^{-1}\right)$, indicating that they are non-electrolytes. The magnetic moment values $(2.50$ 3.54B.M) showed that, the metal ions in the complexes are paramagnetic in nature. Decomposition temperatures of the complexes were found to be in the range of $\left(275-283^{\circ} \mathrm{C}\right)$. Job's method of continuous variation revealed that, the metal complexes are in 1:1 MetalLigand ratio. The physical and analytical data coupled with shift of spectral peaks of the Schiff base in the complexes suggested that the Schiff base act as tetradentate ligand towards metal ion and coordinated via the azomethine- $N$, deprotonated phenolic- $O$ and $S=O$ group of the sulphanilamine. The synthesized ligand and its respective metal complexes were screened for their antibacterial activity against Staphylococcus aureus (Gram-positive), Escherichia coli, (Gram-negative) bacterial strains and antifungal activity against Mucor inducus spp and Aspergillus fumigatus. The results revealed that, the Schiff base and the metal complexes showed significant antibacterial and antifungal strength at high concentrations

Keyword: Synthesis, characterization sulphanilamine, salicylaldehyde, Schiff base

INTRODUCTION

Sulphanilamine and its derivatives such as, sulfapyridine, sulfathiazole and sulfadiazine has for long being used as an effective chemotherapeutic agents employed systematically for the prevention and cure of bacterial infections in humans (Maria et al, 2003). Though the popularity and applications of the sulphanilamine rapidly decrease with the introduction of penicillin and other antibiotics, they are still considered as useful in certain therapeutic fields, especially in the case of ophthalmic infections as well as infections in the urinary and gastrointestinal tract (Maria et al, 2003). Their use as antibiotic is due to their tendency to acts as metabolites which obstruct folic acid synthesis in the bacteria, causing their cell to die (Omoruyi, et al 2015). The presence of azomethine group in addition to the sulphanamide functional group enhance the antimicrobial activity, the extent of the activity may be further be improve on complexation due to chelation (Sofian et al 2012).

MATERIALS AND METHODS

All the reagents and solvents used were of analytical grade and were used without further purification. The glassware used in this work were washed with detergent, rinsed with distilled water and dried in an oven at $110^{\circ} \mathrm{C}$ before use. All weighing were carried out on an electric Metler balance model B154, melting point and decomposition temperature were determined using Galen Kamp melting point apparatus. Molar conductivity was determined using Jen way 4010 model conductivity meter. Magnetic susceptibility measurement was carried out at room temperature using a magnetic susceptibility Gouy balance (MK1 model). FTIR analysis was conducted using Fourier Transform Infrared spectrophotometer, Agilent Technologies Cary model $\left(650-4000 \mathrm{~cm}^{-}\right.$ $\left.{ }^{1}\right)$. Bacterial (Escherichia coli, Staphylococcus aureus, and fungal isolates (Mucor inducus spp and Aspergillus fumigatus) were obtained and identified at the Department of Microbiology, Bayero University Kano. Nutrient Agar (NA) and Sabouraud Dextrose Agar (SDA) were used as bacterial and fungal culture media respectively.

Preparation of Schiff Base

Sulphanilamine $(3.444 \mathrm{~g}, 0.02 \mathrm{~mol})$ was mixed with salicylaldeyde $(4.485 \mathrm{~g}, 0.04 \mathrm{~mol})$ in $50 \mathrm{~cm}^{3}$ of ethanol. 
The resulting mixture was left under reflux for $2 \mathrm{hrs}$. Upon cooling, the obtained light yellow crystalline precipitates were filtered, washed with diethyl - ether and then finally dried in desiccators over $\mathrm{CaCl}_{2}$. (Ümmühan et al., 2008).

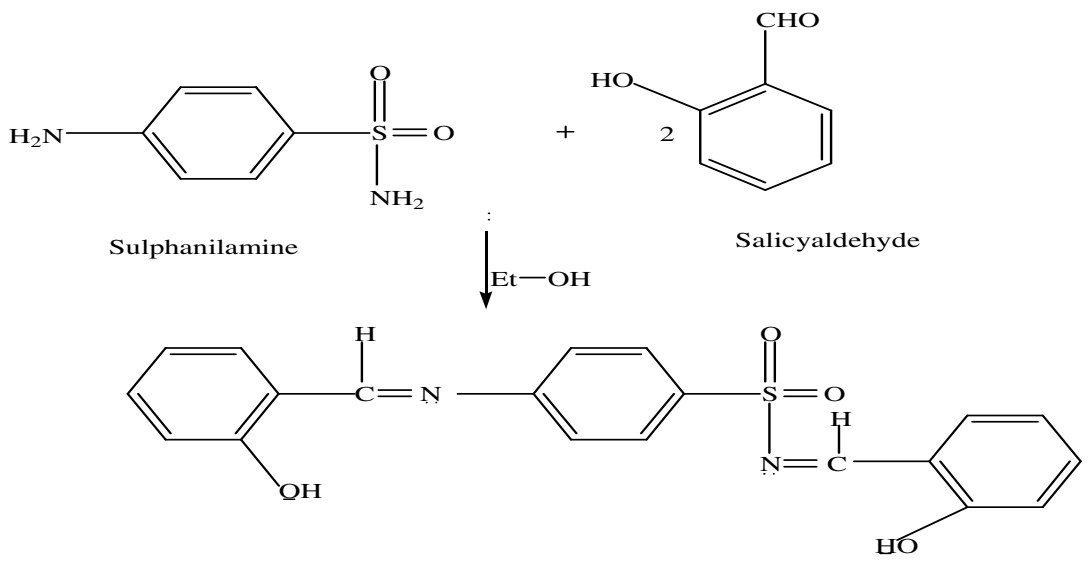

Scheme 1: Formation of Schiff base Preparation of Schiff Base Metal Complexes The metal complexes were synthesized by mixing an ethanolic solution $\left(50 \mathrm{~cm}^{3}\right)$ of the Schiff base $(0.02 \mathrm{~mol})$ with an ethanolic solution $\left(50 \mathrm{~cm}^{3}\right)$ of the metal (II) chloride $(0.01 \mathrm{~mol})$. The resulting mixture was refluxed for 2 hours and left in an ice bath for 3hours. The solid complexes formed were collected by filtration, washed with a small volume of ethanol and diethyl ether, and then dried in desiccator over $\mathrm{CaCl}_{2}$ (Ümmühan et al., 2008).

\section{Determination of Metal to Ligand Ratio}

Number of ligand coordinated to the metal ion was determined using Job's method of continuous variation (Angelici, 1971). 3mmol aqueous solution of the ligand and the metal chlorides were prepared. The following Ligand to Metal salt ratio $(\mathrm{ml}) ; 0: 10,1: 9,2: 8,3: 7,4: 6$, $5: 5,6: 4,7: 3,8: 2,9: 1$ were taken from the ligand solution and each of the metal chloride solutions respectively. A total volume of $16 \mathrm{ml}$ was maintained (in that order) throughout the process and the mole fraction of the ligand was calculated in each mixture. The solutions of the metal chlorides were scanned (as blank) to find the wavelength of maximum absorption $\left(\lambda_{\max }\right)$ for that particular metal ion (Angelici, 1971). The absorbance values were plotted against mole fraction of the ligand and the number of coordinated ligand (coordination number) was determined using the relation below:

$$
\bar{n}=\frac{x_{i}}{1-x_{i}}
$$

Where $\bar{n}=$ number of coordinated ligand, and $\mathrm{x}_{\mathrm{i}}=$ mole fraction at maximum absorbance

\section{Antibacterial Activity Test}

The ligand and the complexes were dissolved separately in DMSO to have three different concentrations $(15 \mu \mathrm{g}, 30 \mu \mathrm{g}$ and $60 \mu \mathrm{g})$ per disc. They were placed on the surface of the culture media (nutrient agar) and incubated at $37^{\circ} \mathrm{C}$ for $24 \mathrm{hrs}$. Then in vitro antibacterial activity against Staphylococcus aureus (Gram-positive), Escherichia coli (Gram-negative)of these ligands and complexes were carried out by disc diffusion method. The diameter of zone of inhibition by the ligand and complexes was compared with the standard drug (Yusha'u and Sadisu, 2011).

\section{Antifungal Activity Test}

The ligand and complexes were dissolved separately in DMSO to have three different concentrations $(15 \mu \mathrm{g}, 30 \mu \mathrm{g}$ and $60 \mu \mathrm{g})$ per disc. They were placed on the surface of the culture media (sabouraud dextrose agar) and incubated at room temperature for $48 \mathrm{hrs}$. Then in vitro antifungal activity against Mucor inducus spp and Aspergillus fumigatus of these ligands and complexes were carried out by disc diffusion method. The diameter of zone of inhibition produced by the ligands and complexes was compared with the standard drug (Hassan et al., 2006).

\section{RESULTS AND DISCUSSION}

The Schiff base was prepared as yellow solid crystals with a modest yield of $55.8 \%$ as shown in scheme 1. Treatment of the prepared Schiff bases with $\mathrm{Co}(\mathrm{II})$ and $\mathrm{Ni}$ (II) chloride afforded the $\mathrm{Co}$ (II) and $\mathrm{Ni}$ (II) complexes respectively. The Co(II) complex was orange in colour with a good yield of $88.5 \%$ while the $\mathrm{Ni}$ (II) complex was light green with a yield of $83.5 \%$ (Table 1 ). The colour may be attributed to the presence of the azomethine group in the Schiff base. 
Table 1. Physical Properties of the ligand and its corresponding metal (II) Complexes

\begin{tabular}{llllc}
\hline Compound/Ligand & Colour & $\begin{array}{l}\text { Percentage } \\
\text { Yield }(\%)\end{array}$ & $\begin{array}{l}\text { Melting } \\
\text { Point }\left({ }^{\circ} \mathrm{C}\right)\end{array}$ & $\begin{array}{l}\text { Decomposition } \\
\text { Temperature }\left({ }^{\circ} \mathrm{C}\right)\end{array}$ \\
\hline Ligand, $\mathrm{L}$ & Yellow & 55.8 & 198 & \\
{$[\mathrm{CoL}]$} & Orange & 88.5 & & 275 \\
{$[\mathrm{NiL}]$} & Light green & 83.7 & & 283 \\
\hline
\end{tabular}

Where $\mathrm{L}=\mathrm{C}_{13} \mathrm{H}_{14} \mathrm{O}_{4} \mathrm{~N}_{2} \mathrm{~S}$

The complexes were found to be air stable with decomposition temperatures of 275 and $283^{\circ} \mathrm{C}$ for the cobalt(II) and nickel (II) complexes respectively. The relatively higher values indicate coordination of the metal to the Schiff base and the formed complexes are relatively stable. Solubility of the ligand and the corresponding metal complexes were determined in some common solvents; the ligand was found to be soluble in acetone but insoluble in water. The solubility improves upon complexation which may be due to increase in polarity as the complexes were formed (Table 2).

Table 2: Solubility of the ligand and its metal (II) complexes in some common solvents

\begin{tabular}{lccccccccc}
\hline Compound & $\mathrm{H}_{2} \mathrm{O}$ & $\mathrm{EtOH}$ & $\mathrm{MeOH}$ & $\mathrm{DMSO}$ & \multicolumn{2}{c}{ Acetone Diethyl } & $\mathrm{CHCl}_{3}$ & $\begin{array}{l}\mathrm{n}- \\
\text { ether }\end{array}$ & $\mathrm{CCl}_{4}$ \\
\hline Ligand, L & IS & SS & IS & S & S & IS & IS & SS & SS \\
{$[\mathrm{CoL}]$} & IS & SS & SS & S & S & IS & SS & IS & IS \\
{$[\mathrm{NiL}]$} & IS & SS & SS & S & SS & IS & IS & SS & IS \\
\hline
\end{tabular}

KEY: $\quad L=\mathrm{C}_{13} \mathrm{H}_{14} \mathrm{O}_{4} \mathrm{~N}_{2} \mathrm{~S}$

$\mathrm{S}=$ Soluble, $\mathrm{SS}=$ Slightly Soluble, $\mathrm{IS}=$ Insoluble, $\mathrm{DMSO}=$ Dimethyl Sulfoxide.

Molar conductance of the complexes $\left(10^{-}{ }^{3} \mathrm{M}\right)$ in DMSO were determined, the results are as shown in Table 3, which is quite low for an electrolyte. The lower values infer non electrolytic nature of the complexes. The values further support the absence of any counter ion in the compound as the complex Magnetic susceptibility studies indicated that the complexes were paramagnetic as the values (3.54BM for $\mathrm{Co}(\mathrm{II})$ and 2.50BM for $\mathrm{Ni}(\mathrm{II})$ ) are consistent with paramagnetic compounds. These results was in agreement with similar paramagnetic compounds reported in the literature (Housecroft,2008). may be a neutral compound.

Table 3: Molar Conductance of complexes in $\left(1 \times 10^{-}{ }^{3} \mathrm{M}\right)$ in DMSO Solution

\begin{tabular}{|c|c|c|c|}
\hline Complex & $\begin{array}{l}\text { Concentratio } \\
\text { Moldm }^{-3}\end{array}$ & $\begin{array}{l}\text { Specific Conductance } \\
\left(\mathrm{Ohm}^{-1} \mathrm{~cm}^{-1}\right)\end{array}$ & $\begin{array}{l}\text { Molar conductance } \\
\left(\mathrm{Ohm}^{-1} \mathrm{~cm}^{2} \mathrm{~mol}^{-1}\right)\end{array}$ \\
\hline [CoL] & $\begin{array}{l}1 \times 10^{-3} \\
1 \times 10^{-3}\end{array}$ & $\begin{array}{l}32.6 \times 10^{-6} \\
314 \times 10^{-6}\end{array}$ & $\begin{array}{l}32.6 \\
31.4\end{array}$ \\
\hline \multicolumn{4}{|c|}{$\begin{array}{l}\mathrm{L}=\mathrm{C}_{13} \mathrm{H}_{14} \mathrm{O}_{4} \mathrm{~N}_{2} \mathrm{~S} \\
\text { Table: 4: Magnetic susceptibility values of the metal (II) complexes }\end{array}$} \\
\hline $\begin{array}{l}\text { Complex } \\
\text { Compound }\end{array}$ & $\begin{array}{l}\text { Mass Susceptibility }(\mathrm{Xg}) \\
\left(\mathrm{g}^{-1}\right)\end{array}$ & $\begin{array}{l}\text { Molar Susceptibility } \\
\quad(\mathrm{Xm})\left(\mathrm{mol}^{-1}\right)\end{array}$ & $\mu_{\mathrm{eff}}(\mathrm{B} . \mathrm{M})$ \\
\hline $\begin{array}{l}{[\mathrm{CoL}]} \\
{[\mathrm{NiL}]}\end{array}$ & $\begin{array}{l}16.2 \times 10^{-6} \\
8.07 \times 10^{-6}\end{array}$ & $\begin{array}{l}0.0053 \\
0.0026\end{array}$ & $\begin{array}{l}3.54 \\
2.50\end{array}$ \\
\hline
\end{tabular}

The infrared spectral result of the Schiff base ligands showed vibrational peak at $1311 \mathrm{~cm}^{-1}$ and $1317 \mathrm{~cm}^{-1}$ which may be attributed to the $\mathrm{v}(\mathrm{S}=0)$ group (Byeong et al, 1996). A peak at $1615 \mathrm{~cm}^{-1}$ in the Schiff base affirmed the presence of $(\mathrm{C}=\mathrm{N})$ indicating the formation of the ligand, which shifted to the range of $1615 \mathrm{~cm}^{-1}-1607 \mathrm{~cm}^{-1}$ which is an indication of the participation of the azomethine nitrogen in coordination to the metal ions. New absorption bands in the range of $700 \mathrm{~cm}^{-1}$ and $540 \mathrm{~cm}^{-1}$ in the metal (II) complexes indicate the formation of $\mathrm{M}-\mathrm{N}$ and $\mathrm{M}-\mathrm{O}$ bonds respectively. This indicates that the ligands are coordinated to the metal ions through these donor atoms. The results are shown in Table 5. 
Special Conference Edition November, 2017

Table: 5: Infrared spectral Data of the Ligands and metal (II) complexes

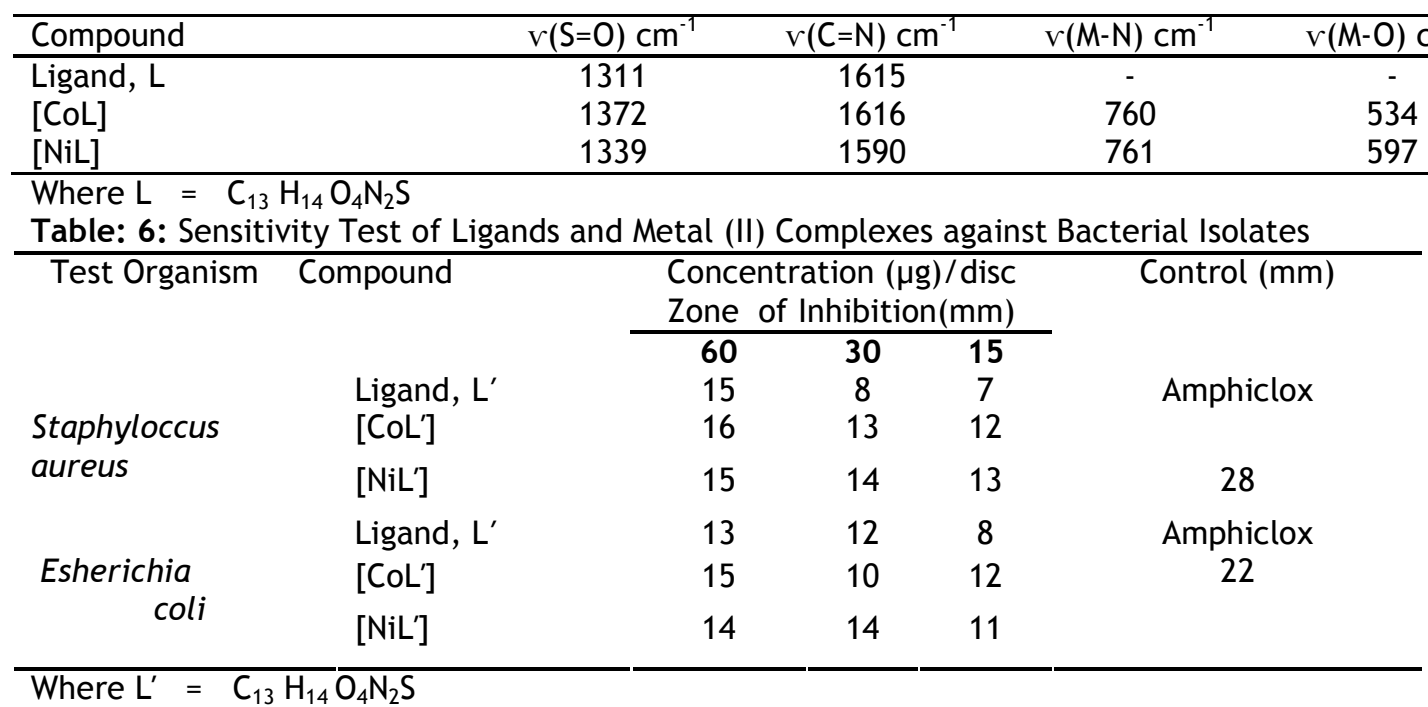

Table: 7: Sensitivity Test of Ligands and Metal (II) Complexes against Fungal Isolates

\begin{tabular}{|c|c|c|c|c|c|}
\hline \multirow[t]{2}{*}{ Test Organism } & \multirow[t]{2}{*}{ Compound } & \multicolumn{3}{|c|}{$\begin{array}{l}\text { Concentration }(\mu \mathrm{g}) / \text { disc } \\
\text { Zone of Inhibition }(\mathrm{mm})\end{array}$} & \multirow[t]{2}{*}{ Control (mm) } \\
\hline & & 60 & 30 & 15 & \\
\hline \multirow{3}{*}{ Aspergillus formigatus } & Ligand, L & 15 & 12 & 10 & \multirow[t]{2}{*}{ Griseofulvin } \\
\hline & [CoL] & 17 & 15 & 10 & \\
\hline & {$[\mathrm{NiL}]$} & 16 & 14 & 12 & 32 \\
\hline \multirow{2}{*}{ Mucor spp. } & Ligand, L & $\begin{array}{l}20 \\
28\end{array}$ & 15 & 14 & \multirow[b]{2}{*}{31} \\
\hline & [NiL] & 20 & 18 & 16 & \\
\hline
\end{tabular}

Where $\mathrm{L}=\mathrm{C}_{13} \mathrm{H}_{14} \mathrm{O}_{4} \mathrm{~N}_{2} \mathrm{~S}$

Estimation of the Metal to Ligand ratio was achieved by using Job's method of continuous variation (Angelici, 1971). The results showing mole fraction of the Ligand and absorbance for the respective metal ions $\left(\mathrm{Co}^{2+}\right.$ and $\left.\mathrm{Ni}^{2+}\right)$ was used in calculating the number of coordinated ligand, and the results suggested 1:1 MetalLigand ratio in all the complexes.

The antibacterial activity for both Schiff bases and their metal (II) complexes were determined using disc diffusion method. The Schiff base and the complexes showed little activity against the entire tested organism at all concentrations though the complexes showed activity high activity than the ligand (Table 6). The antifungal activity studies of the compound showed the Schiff bases are low in activity against Aspergillus formigatus but there is a significant activity against Mucor inducus species as expected the higher concentrations records higher activity against the fungal isolates as shown in Table 7.

\section{CONCLUSSION}

Schiff base derived from condensation of salicyaldehyde and sulphanilamine was synthesized. Its $\mathrm{Co}(\mathrm{II})$ and $\mathrm{Ni}$ (II) complexes were also prepared from the reaction of ethanolic solution of the Schiff bases and metal (II) chloride. Characterization of the complexes indicates that, they are non-electrolytic. The decomposition temperature of the metal Schiff base revealed high values which is an indication of high stability. The solubility test carried out in various solvents, showed they are all soluble in DMSO. IR- spectroscopy indicated the Schiff base ligands are coordinated to the central metal ions. The antimicrobial activity of the ligands and their metal complexes indicated that the metal (II) complexes were more active than the free Schiff bases on one or more isolates. 


\section{REFERENCES}

Angelici, R.J. (1971): "Synthesis and Techniques in Inorganic Chemistry", W.B Savders Company, $2^{\text {nd }}$ edition, pp 115-125

Byeong G. Chae D., Hae N., Hyung K. C. and Yong K. C. (1996); Synthesis and characterization of schiff base derived 2hydroxy napthaldehyde and aliphatic diammines. Bulletin Korean Chemical Society 17(8): 687-693

Hassan S. W., Umar R. A., Lawal M., Bilbis L. S. and Muhammad B. Y. (2006): Evaluation of antifungal activity of Ficus sycomorus (moraceae). Biological and Environmental Science Journal for the tropics 3(2), 18-25.

Housecroft, C.E., Sharpe, A.G. (2008). Inorganic Chemistry, $3^{\text {rd }}$ ed., Pearson Education Ltd., Harlow, England, pp 637682.

Maria, H., Torre, Gianella, F., Eduardo, K., Edurdo, E. (2003). Characterization of a $\mathrm{Cu}(\mathrm{II})$ complex of sulfadimethoxine. Journal of Inorganic Biochemistry. (94): 200-204.
Omoruyi G.I, Alexander P. S. Anthony J. A. Eric C. H. (2015); Synthesis and Characterization of Bioactive Acylpyrazolone Sulfanilamides and Their Transition Metal Complexes: Single Crystal Structure of 4-Benzoyl-3methyl-1-phenyl-2-pyrazolin-5-one Sulfanilamide. Bioinorganic chemistry and application, 2015.

Sofian S., Mohamed A. A., Salah M. B. Mousa I. J, Tariq A. (2012) Synthesis and biological screening of some new sulfanilamide Schiffs base. International Journal of Pharmaceutical Science, 5,(Suppl 1), 38-40

Ummuhan, O., Pinar, O. Ertain, S., Fatima, H. (2007). Characterization and antibacterial 4 activity of new sulfonamide derivates and their nickel (II), cobalt (II) complexes. Inorganic Chimica Acta (362): 2613 -2618.

Yusha'u M. and Sadisu F. U. (2011): Inhibition activity of detarium microcarpum extracts on some clinical bacterial isolates. Biological and Environmental Science Journal for the tropics 8(4): 113-117. 